\title{
VILJELYSKASVIEN VEDENKESTÄMISKYVYSTÄ.
}

\author{
Pentti Saukko.
}

Saimaan säännöstelytoimisto, Helsinki.

Saapunut 2. IV. 1946

Kasvupohjan liiallinen kosteus aiheuttaa viljelyskasvien kehitykselle pysyviä häiriöitä. Näin syntyneen vahingon suuruus on riippuvainen paitsi eri kasvilajeista myös siitä, kauanko tällainen epäedullinen olotila kestää, sekä siitä mihin aikaan kasvukaudesta tämä sattvu. Kasvien kärsimän vesivahingon suuruuden ilmaisee käyrä, joka osoittaa sadon riippuvaisuuden määräävästä vedenkorkeudesta ja täten siis myös suhteellisen vesivahingon eri korkeuksilla (vesivahinkokäyrä). Tuhoutumisrajalla tarkoitetaan rajaa, minkä alápuolelta vesi on tuhonnut kasvillisuuden, ja vahinkorajalla korkeutta, mihin saakka veden vahingollinen vaikutus on ulottunut. Nämä kasvurajat määräävät käyrän ala- ja yläpisteen. Tässä yhteydessä rajoitutaan tarkastamaan yliveden (tulvan) — siis verraten lyhytaikaisen vedenkorkeuden — viljelyskasveille aiheuttamaa vahinkoa.

Ulkomaisesta kirjallisuudesta ei ole löydettävissä paljoakaan tietoja viljelyskasvien vedenkestämiskyvystä, eivätkä siellä suoritetut tutkimukset vastaa olosuhteitamme. Maassamme Kaitera $(2,4)$ on Tikkurilassa Maatalouskoelaitoksessa vv. 1934 - 36 suorittamiensa astiakokeiden avulla selvittänyt kysymystä, missä määrin tärkeimmät viljelyskasvimme kestävät kasvukauden alussa sattuvaa vesipeittoa. Näiden tutkimusten lisäksi hän on suorittanut myös silmävaraisia vesivahinkoa koskevia havaintoja eri vesistöjen tulvanalaisilla rantapelloilla. Myös useat vedenjärjestelyhankkeiden piirissä toimivat maanviljelysinsinöörit ovat tehneet tällaisia havaintoja $(3,6)$. Vuonna 1938 perustetulla Maasojan koekentällä Vihdissä on suoritettu mataloushallituksen vesiteknillisten tutki$\mathrm{m}$ u s t e n yhteydessä usean vuoden aikana laajoja vesivahinkotutkimuksia lähinnä kuivatus- ja vesityskysymysten selvittämiseksi. Tämän vuoksi on niissä tutkittu pääasiassa korkean pohjaveden vaikutusta satotulokseen. Kirjoittaja (5) on v. 1938 Saimaan ranta-alueella suorittanut tutkimuksia heinä-elokuun vaihteessa - siis viljakasvien kasvuajan loppupuolella — pelloille nousseen yliveden vaikutuksesta viljelyskasveihin. Näissä tutkimuksissa on pääasiassa jyviin kohdistuvien mittausten perusteella seurattu myös eri morfologisten ominaisuuksien riippuvaisuutta vedenkorkeudesta. 
Kesällä 1945 ilmaantui kirjoittajalle tilaisuus, valvoessaan S a i m a a n säännöstely toimiston rantatutkimustöitä Sotkamon reitin varrella, jatkaa vesivahinkoa koskevia tutkimuksia. Ylivesi sattui tällöin kesäkuun loppupuolella. Yliveden sattumisaikaan nähden tällöin tehdyt havainnot täydentävät varsin sopivasti KAITERAn ja kirjoittajan aikaisempia tutkimuksia, ja eri tutkimukset muodostavat kokonaisuutena eräänlaisen havaintosảrjan, jonka perusteella voidaan tehdä päätelmiä viljelyskasviemme vedenkestämiskyvystä ja syntyneen vesivahingon laadusta kasvukauden eri aikoina. Tämä esitykseni keskittyy näiden v. 1945 suoritettujen tutkimusten selostamiseen. Lopuksi tarkastelen lyhyesti käsiteltävänä olevaa kysymystä eri tutkimuksiin nojautuen.

\section{Vuoden 1945 tutkimukset.}

1. Tutkimusalue ja -olosuhteet. Tutkimukset keskittyivät Sotkamon kuntaan kuuluvien Kiimas- ja Pirttijärven sekä osaksi myös Nuasjärven rantapelloille. Näistä järvialtaista káksi ensiksi mainittua on aliveden aikana käytännöllisesti kătsoen samassa tasossa, mutta yliveden aikana niillä on jonkin senttimetrin putousero. Nuasjärvi on, vesimäärästä riippuen, $10-100 \mathrm{~cm}$ tätä tasoa alempana. Hydrografisella toimistolla on päivittäin luettavat vedenkorkeusasteikot Kiimas- ja Nuasjärven rannalla, mutta suoritettavia tutkimuksia varten kirjoittaja oli sijoittanut tarkkavaakitustasoon verratun asteikon myös Pirttijärveen. Koska Kiimas- ja Pirttijärven vedenkorkeuksien ero oli tutkimustuloksiin vaikuttavana aikana koko ajàn $7 \mathrm{~cm}$, niin Kiimasjärven havainnot on redusoitu tällä korkeuserolla Pirttijärven havainnoiksi. Pirttijärven ja Nuasjärven v e d e n k o r k e ud e t käyvät ilmi piirroksesta 1. Pirttijärvessä ylin vesi (HW) oli 138.80 NN-tasossa ja se sattui aikana 18.-23. VI. Nuasjärvessä ylin vesi oli päivää myöhemmin tasossa 138.21. Yliveden huippu oli kummassakin järvessä selväpiirteinen ja verraten laakea. 30 vrk. kestävän ylivesikummun keskivesi (MW 30 vrk) oli Pirttijärvessä 138.71 ja Nuasjärvessä 138.16, siis ylintä vettä vain 9 ja $5 \mathrm{~cm}$ alempana.

Piirrokseen 1 on edelleen merkitty päivittäiset s a d e k o r k e u d e t, jotka on mitattu tutkimusalueen välittömässä läheisyydessä sijaitsevan Ilmatieteellisen keskuslaitoksen Kuninkaanniemen havaintoasemalla. Toukokuu oli vähäsateinen, kun taas kesäkuun alkupuoli oli erityisen sateinen. Heinä-elokuun vaihteessa sattui verraten pitkä poutakausi, joka álensi varsinkin kevättoukojen satoja. Seuraavasta yhdistelmästä käyvät selville kesäkuukausien sademäärät ja keskilämpötilat sekä vertauksen vuoksi vastaavat keskiarvot vuosijaksolta 1921 -45. ${ }^{1}$

Kuukausi

Sademäärä, mm

v. $1945 \quad$ vv. $1921-45$

Lämpötila, ${ }^{\circ} \mathrm{C}$

\begin{tabular}{rrrr}
$\mathrm{V}$ & $\ldots \ldots \ldots \ldots$ & 17.5 & 42.2 \\
$\mathrm{VI}$ & $\ldots \ldots \ldots \ldots$ & 125.0 & 64.7 \\
$\mathrm{VII}$ & $\ldots \ldots \ldots \ldots$ & 27.0 & 63.5 \\
$\mathrm{VIII}$ & $\ldots \ldots \ldots \ldots$ & 119.3 & 71.2 \\
\hline
\end{tabular}

v. 1945 vv. $1921-45$

$5.5 \quad 7.0$

$12.2 \quad 12.5$

$17.0 \quad 16.5$

VIII $\ldots \ldots \ldots \ldots \ldots \quad 119$

$241.6 \quad$ Keskim. 12.6

14.1

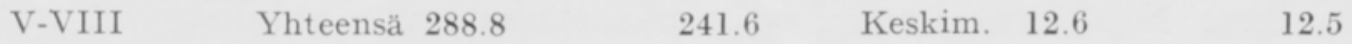

${ }^{1}$ Lämpötila-arvot on mitattu Kajaanissa. Sademittausten puuttuessa Kuninkaanniemestä vuosilta 1921 - 32 arvot on otettu lähimpien havaintoasemien vertailuna. 


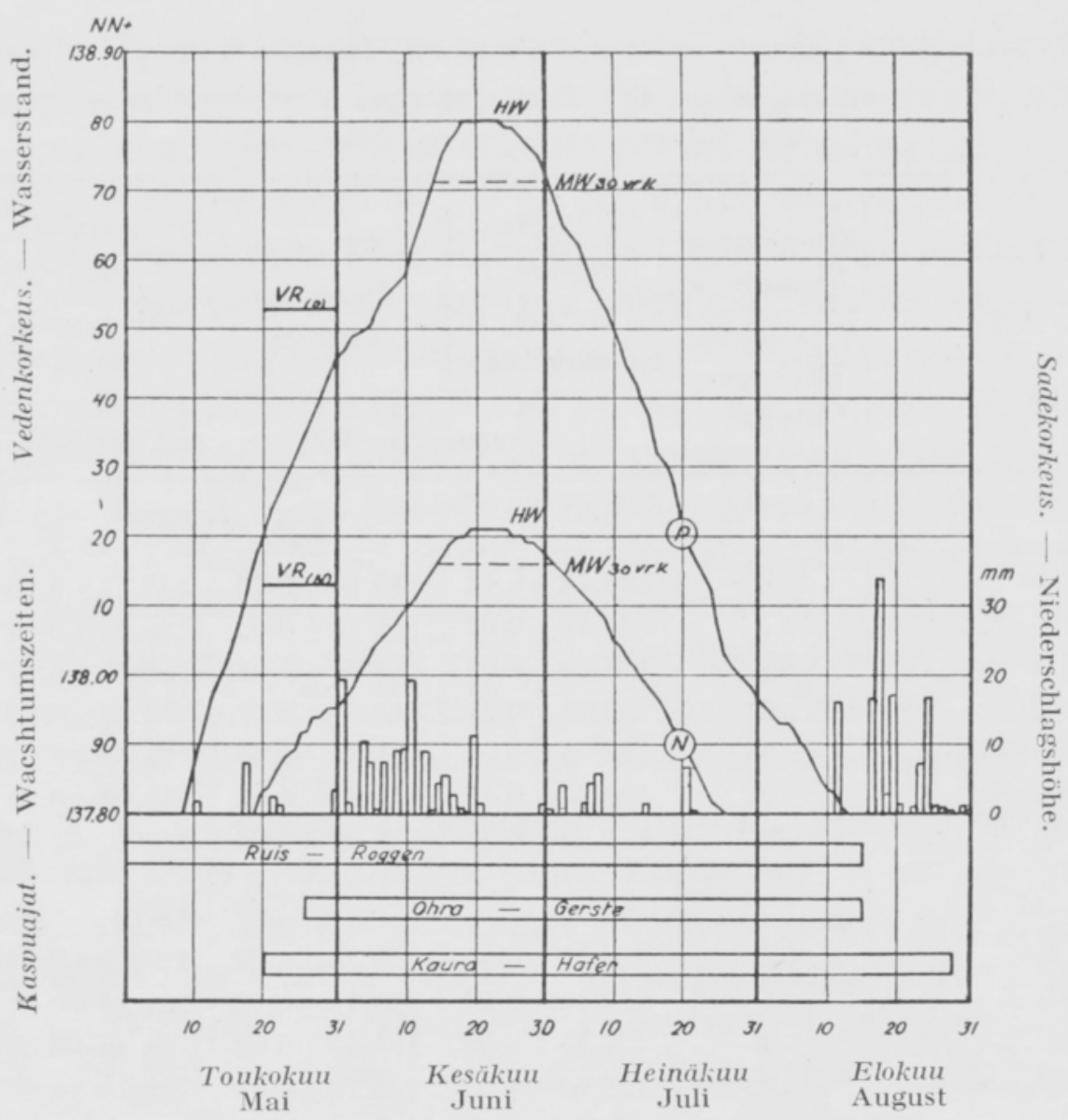

Piirros I. Pirttijärven (P) ja Nuasjärven (N) vedenkorkeudet, tutkimusaluetta vastaavat päivittäiset sadekorkeudet sekä viljakasvien keskimääräiset kasvuajat kesällä I945. Fig. 1. Die Wasserstärde des Pirttijärvi und des Nuasjärvi, die dem Untersuchungsgebiet entsprechenden täglichen Niederschlagshöhen sowie die durchschnittlichen Wachstumszeiten der Kulturpflanzen im Sommer 1945.

Vertailu osoittaa sateiden poikkeuksellisen jakautumisen kesänä 1945, kun taas lämpötila näyttää vastanneen suunnilleen normaalia. Esitettäköön vielä, että 30 vrk. kestävää ylivesikumpua vastaavana aikana (Pirttijärvessä 8. VI-7. VII) sademäärä oli $89.7 \mathrm{~mm}$, joka on n. $3 \mathrm{~mm}$ vuorokautta kohden. Tämä merkitsee, että maà oli sateiden johdosta verraten kosteaa yliveden sattuessa.

Pirttijärven rannalla ulottuvat alimmat pellot suunnilleen korkeudelle 138.30, vaikkakin kannattavan peltoviljelyksen alarajana on pidettävä keskimäärin korkeutta n. 138.50. Keväällä 1945 lumet sulivat aikaisin pelloilta, ja kun toukokuu oli vähäsateinen, niin ei erityisen korkeaa tulvaa pelätty, vaan pellot muokattiin ja kylvettiin useimmiten niin alas kuin vedenkorkeus maan upottamisen takia salli. Kevättoukojen vil je ly ks e n a l a r a j a (VR piirroksessa 1) oli Pirttijärvellä keskim. korkeudella 138.53 ja Nuasjärvellä 138.13 (vert. taulukko 1). Kun muokkaustyöt suoritettiin yleisesti aikana 20.-31. V, niin näitä korkeuksia vastasi $\mathrm{n}$. $10-30 \mathrm{~cm}$ kuivavara ${ }^{1}$ (vrt. piirros 1). Mainittakoon, että kuivavaran ollessa $20-30$ $\mathrm{cm}$ muokkaustyö on jo turvemailla hankalaa. Vedenkorkeuskäyriä tarkastelemalla voidaan ymmärtää rantaviljelijöiden rohkeus tulvavaaraan nähden, kun otetaan vielä

$1 \mathrm{Ku}$ ivava ra $=$ maanpinnan ja järven vedenpinnan korkeusero. 
Taulukko I. Viljelyskasvien kasvurajoja koskevat maastossa tehdyt havainnot kesällä I945.

Tabelle 1. Im Gelände angestellte Beobachtungen über die Wachstumsgrenzen der Kulturpflanzen im Sommer 1945.

\begin{tabular}{|c|c|c|c|c|c|}
\hline \multirow[t]{2}{*}{ Laji - Art } & \multirow{2}{*}{$\begin{array}{c}\text { Havaintojen } \\
\text { lukumäärä } \\
\text { Anzahl der } \\
\text { Beobach- } \\
\text { tungen }\end{array}$} & $\begin{array}{c}\text { Viljelyksen } \\
\text { alaraja } \\
\text { Untere } \\
\text { Kulturgrenze }\end{array}$ & $\begin{array}{c}\text { Alin kasvi } \\
\text { Unterste } \\
\text { Pflanze }\end{array}$ & $\begin{array}{l}\text { Tuhoutumis- } \\
\text { raja } \\
\text { Abgangs- } \\
\text { grenze }\end{array}$ & $\begin{array}{c}\text { Vahinkoraja } \\
\text { Schaden- } \\
\text { grenze }\end{array}$ \\
\hline & & \multicolumn{4}{|c|}{ korkeudella $\mathrm{NN}+$ — auf der Höhe $\mathrm{NN}+$} \\
\hline & & \multicolumn{4}{|c|}{ PIRTTIJÄRVI } \\
\hline Ruis - Roggen ...... & 3 & $138.48 \pm 0.12$ & $138.65 \pm 0.04$ & $138.77 \pm 0.00$ & $138.94 \pm 0.01$ \\
\hline Ohra - Gerste......... & 4 & $138.49 \pm 0.02$ & $138.79 \pm 0.02$ & $138.85 \pm 0.01$ & $139.02 \pm 0.03$ \\
\hline Kaura - Hafer ........ & 11 & $138.54 \pm 0.05$ & $138.74 \pm 0.01$ & $138.80 \pm 0.01$ & $138.98 \pm 0.01$ \\
\hline Apila - Klee ......... & 8 & $138.44 \pm 0.07$ & $138.79 \pm 0.01$ & $138.80 \pm 0.00$ & \\
\hline Timotei-Timothee ... & 9 & $138.39 \pm 0.06$ & $138.58 \pm 0.03$ & $138.65 \pm 0.02$ & \\
\hline Peruna - Kartoffel .... & 2 & $138.58 \pm 0.08$ & $138.86 \pm 0.02$ & $138.90 \pm 0.01$ & $139.10 \pm 0.04$ \\
\hline Pellava-Lein $\ldots . .$. . & 2 & $138.54 \pm 0.11$ & $138.70 \pm 0.05$ & $138.75 \pm 0.02$ & $138.90 \pm 0.03$ \\
\hline . & & \multicolumn{4}{|c|}{ NUASJ ÄRVI } \\
\hline Ohra-Gerste... & 2 & $138.17 \pm 0.02$ & $138.22 \pm 0.04$ & $138.28 \pm 0.01$ & $138.50 \pm 0.00$ \\
\hline Kaura-Hafer .... & 5 & $138.12 \pm 0.03$ & $138.15 \pm 0,02$ & $138.22 \pm 0.01$ & $138.35 \pm 0.01$ \\
\hline Apila - Klee .......... & 4 & $138.15 \pm 0.02$ & $138.17 \pm 0.02$ & $138.22 \pm 0.00$ & \\
\hline Timotei - Timothee .... & 4 & $138.04 \pm 0.03$ & $138.11 \pm 0.01$ & $138.13 \pm 0.01$ & $=$ \\
\hline
\end{tabular}

huomioon, että yliveden sattumisaika on vesistössä keskim. 5. VI. Vesi olisi tuskin noussut viljelyksen alarajan korkeudelle, elleivät kesäkuun sateet olisi aiheuttaneet uutta vedenpinnan nousua. Pirttijärven alimmat viljelykset joutuivat veden alle kesäkuun alkupäivinä ja vapautuivat vedestä vasta runsaan kuukauden kuluttua.

Piirrokseen 1 on vielä merkitty rukiin, ohran ja kauran $\mathrm{ka} \mathrm{s} \mathrm{v} \mathrm{u} \mathrm{a} \mathrm{j} \mathrm{a} \mathrm{t,} \mathrm{jotka}$ vastaavat alueen keskimääräisiä viljan kylvö- ja kypsymisaikoja. Tämän mukaan oli ohran (4-tahkoiset) kasvuaika n. 80 vrk. ja kauran (pääasiassa Kytö) keskimäärin 100 vrk. Mainittakoon, että rukiin heilimöiminen tapahtui heinäkuun 5. ja 12 . päivän välisenä aikana ja että ohra tuli yleisesti tähkälle heinäkuun puolivälissä ja kaura heinäkuun 20. päivän tienoilla.

2. Silmävaraiset kasvurajoja koskevat havainnot. Yliveden laskeuduttua kirjoittaja suoritti silmävaraisia havaintoja siitä, miten eri viljelyskasvit olivat kestäneet vesipeittoa ja kuinka korkealle kasvustossa vesivahinkoa oli todettavissa. Kysymykseen tuli siis pääasiassa t u hou t u m i s- ja v a h i n k o r a j a n määritteleminen. Tämä tehtiin kuitenkin vasta n. kuukausi yliveden sattumisajan jälkeen, jolloin haitallisen vedenkorkeuden lopullinen vaikutus voitiin jo varmuudella päätellä. Tuhoutumisraja oli muodostunut selväpiirteiseksi melkein kaikissa havaituissa kasvilajeissa. Kasvuston merkittävä harventuminen ja osittain myös ulkonaisten kasvinosien kehityksen hidastuminen oli tapahtunut varsin rajoitetussa korkeusvyöhykkeessä, jolloin eri alueilla vaakitut samaa 
kasvilajia koskevat havainnot eivät sanottavasti eronneet toisistaan. Vahinkoraja määriteltiin korkeudelle, missä kásvusto oli yhtä tiheätä kuin ylempänä, eikä eri morfologisten ominaisuuksien kehityksessä voinut maastossa havaita heikentymistä. Tämän kasvurajan arvioiminen oli jo paljon epämääräisempi kuin tuhoutumisrajan määrittely. Taulukossa 1 on havaittujen kasvurajakorkeuksien keskiarvot kasvilajeittain. Lisäksi taulukossa on havaintojen lukumäärän lisäksi esitetty vastaavat viljelysten alarajojen keskikorkeudet sekä sarake "alin kasvi», jolla tarkoitetaan korkeutta, missä alimmat kasviyksilöt olivat tavattavissa. Tämän korkeuden ja tuhoutumisrajan välisellä vyöhykkeellä ei satotulokseen nähden ole kuitenkaan käytännöllistä merkitystä, sillä kasvusto oli erittäin harvaa ja kituvaa. Taulukkoon lasketut keskiarvon keskivirheet ${ }^{1}$ osoittavat varsinkin tuhoutumisrajakorkeuksien huomattavan vähäistä hajontaa, mikä merkitsee rajan selväpiirteisyyttä. Havaintoja eri maalajien suhteen ei niiden vähälukuisuuden takia ole eritelty. Mainittakoon, että suurin osa havainnoista on tehty verraten tiiviillä hieta- ja hietàsavimailla. Kauraa koskevista havainnoista noin puolet koskivat turvemaita.

$\mathrm{V}$ i 1 j a k a s v e is t a alimmat ruisyksilöt olivat Pirttijärven rannalla kestäneet kuolematta 20 vrk:n ajan vesipeittoa, ohra vastaavasti 4 vrk. ja kaura 14 vrk. Tuhoutumisrajaa vastaa rukiissa 11 vrk:n vesipeitto. Ohran tuhoutumisrãjâ on 5 cm HW:n yläpuolella ja kauran viimeksi mainitun korkeudella. Vahinkoraja on arvioitu yleensä $15-20 \mathrm{~cm}$ tuhoutumisrajaa korkeammalle. Nuasjärvellä tehdyt havainnot tukevat edellä esitettyä. Kevätvehnäviljelykset eivät ulottuneet niin alas, että niillä olisi voitu tehdä vastaavia havaintoja.

Erillisenä - kuitenkin verraten poikkeuksellisena - Pirttijärven havaintona mainittakoon, että 20. VI todettiin n. $55 \mathrm{~cm}: n$ pituisia, kasvukykyisiä, vielä tähkättömiä rukiin korsia korkeudelta 138.64. Korret olivat seisoneet vedessä 10 vrk. ja vesipeiton vahvuus oli havaintopäivänä $16 \mathrm{~cm}$. Elonkorjuun aikana suoritettiin paikalla uusi tarkastus, jolloin havaittiin samojen yksilöiden kasvaneen pituutta vielä $10 \mathrm{~cm}$ ja muodostaneen tähkiäkin (pituus $60-65 \mathrm{~mm}$ ), jotka kuitenkin olivat jyvättömiä. Kesän aikana ko. kasvusto oli ollut vedessa 21 vrk. Mainittakoon, ettei tässä eikä muissakaan havainnoissa aallokko ollut päässyt vioittamaan kasvustoa eikä keräämään pellolle kaisla- ja ruokojätteitä, jotka helposti tuhoavat heikon taimiston. - Varsinkin turveperäisillä kauraviljelyksillä saattoi havaita, että jonkin verran tuhoutumisrajan alapuolella olevat kasviyksilöt olivat vielä täysin vihantia muun kasvuston ollessa jo kypsää. Tämän johdosta on todettava, että vähäinen osa kauran siemenistä oli, jouduttuaan veteen n. 2 viikkoa kylvön jälkeen, voinut säilyttää kasvuvoimansa n. 20 vrk. kestäneestä vesipeitosta huolimatta, jolloin kasvunkehitys oli kuitenkin huomattavasti hidastunut. Kuten jo edeltä on ilmennyt, on edellä esitetty kuitenkin käytännön kannalta katsoen vailla merkitystä. Yliveden vaikutuksesta viljan kypsymiseen tehtiin sensijaan huomio, että HW:n yläpuolella vesivahinkoa saanut vilja kypsyi jonkin verran nopeammin kuin vahingoittumaton.

$$
1 \text { Laskettu kaavasta } m= \pm \sqrt{\frac{\varepsilon^{2}}{n(n-1)}}
$$


Nurmikasveista oli puna-apilan tuhoutumisraja erityisen jyrkkä. Se asettui Pirttijärvessä HW:n korkeudelle ja Nuasjärvessä $1 \mathrm{~cm}$ korkeammalle. Vahinkor॰ja näytti olevan suunnilleen sama kuin tuhoutumisraja. Timotein tuhoutumisrajaa oli vaikeampi määritellä, mitä osoittaa tavallaan havaintojen suurempi keskiarvon keskivirhekin. Kummassakin järvessä vastaa tuhoutumisrajaa n. 20 vrk:n vesipeitto. Vahinkoraja ei ainakaan sanottavasti eronnut tuhoutumisrajasta.

M uista kasveista perunaa koskevat kaksi savi- ja hietasavimaalla tehtyä havaintoa osoittivat tuhoutumisrajan (vaon harjan korkeus) olevan keskim. $10 \mathrm{~cm}$ ja vahinkorajan $30 \mathrm{~cm}$ HW:n yläpuolella. Tuhoutumisraja oli verraten selväpiirteinen. - Pellavan vedenkestämiskyky näytti olevan huomattavạn hyvä. Alinta kasvustoa vastasi 17 vrk:n vesipeitto ja varsin epämääräistä tuhoutumisrajaa vain 3 vrk. lyhempiaikainen. Vahinkoraja määriteltiin suunnilleen $15 \mathrm{~cm} \mathrm{HW:n}$ yläpuolelle. Pellavassa saattoi havaita kuten kaurassakin, että vesipeitto oli hidastanut kehitystä. Muun kasvuston valmistuessa olivat nimittäin alimmat yksilöt vielä kukassa.

3. Viljakasvien morfologisia ominaisuuksia koskevat t u t kim u ks e t. Paitsi silmävaraisia vesivahinkoja koskevia havaintoja suoritettiin viljakasveista samanlainen eri morfologisiin ominaisuuksiin kohdistuva tutkimus kuin kirjoittajan v. 1938 tekemässä tutkimuksessa. Tätä varten otettiin vahingoittuneesta viljasta eri korkeuksilta tähkänäytteitä, ${ }^{1}$ jotka käsittivät vähintään 20 tuleentunutta tähkää. Lisäksi tehtiin merkinnät korren pituudesta, maalajista ja kasvutiheydestä. Samalta saralta kerätyt $4-8$ näytettä muodostivat näytesarjan. Mainittakoon vielä, että näytteet otettiin aina n. 2 m:n etäisyydeltä ojasta, jolloin pohjaveden korkeus oli eri näytteisiin nähden sama ja vastasi suunnilleen järven vedenpinnan korkeuttá. Kaikkiaan koko aineisto käsitti n. 100 näytettä, mutta Nuasjärven rannalta otettuja ei kuitenkaan ole niiden vähyyden vuoksi yksityiskohtaisesti käsitelty. Seuraavasta yhdistelmästä käyvät ilmi varsinaisen tutkimusaineiston muodostavan Pirttijärven näytteiden ottamisajat sekä niiden jakautuminen eri viljalajien osalle:

\begin{tabular}{|c|c|c|c|c|}
\hline & $\begin{array}{l}\text { Náytteiden } \\
\text { ottamisaika }\end{array}$ & $\begin{array}{l}\text { Näytesarjojen } \\
\text { lukumäärä }\end{array}$ & $\begin{array}{l}\text { Näytteiden } \\
\text { lukumäärä } \\
\text { sarjassa }\end{array}$ & $\begin{array}{c}\text { Näytteiden } \\
\text { lukumäärä } \\
\text { yhteensä }\end{array}$ \\
\hline Ruis $\ldots \ldots \ldots$ & 13.-15. VIII & 3 & $5-6$ & 16 \\
\hline Ohra.......... & $14 .-15$. VIII & 4 & $4-7$ & 22 \\
\hline Kaura ........ & 27.-29. VIII & 7 & $5-8$ & 44 \\
\hline Koko aineisto & 13.-29. VIII & 14 & $4-8$ & 82 \\
\hline
\end{tabular}

Näytesarjojen lajikkeista mainittakoon, että ruis oli maatiaista, ohra Vegaa ja kaurasta osa oli sekalajikkeisia päälajikkeen ollessa Kytöä.

Havaintoaineisto on käsitelty siten, että kustakin näytteestä on valikoimatta otettu 20 tähkää, joista jokaisesta on mitattu tähkälapakon pituus ja jyvien lukumäärä. Mittausten keskiarvot edustavat vastaavan näytteen t ä h k än pit u u t t a ja jyvälukua. Edelleen on näytteestä Valtion siementarkastuslaitoksessa

1 Röyhy sisällytetään seuraavassa lyhyyden vuoksi tåhkä-käsitteeseen. 


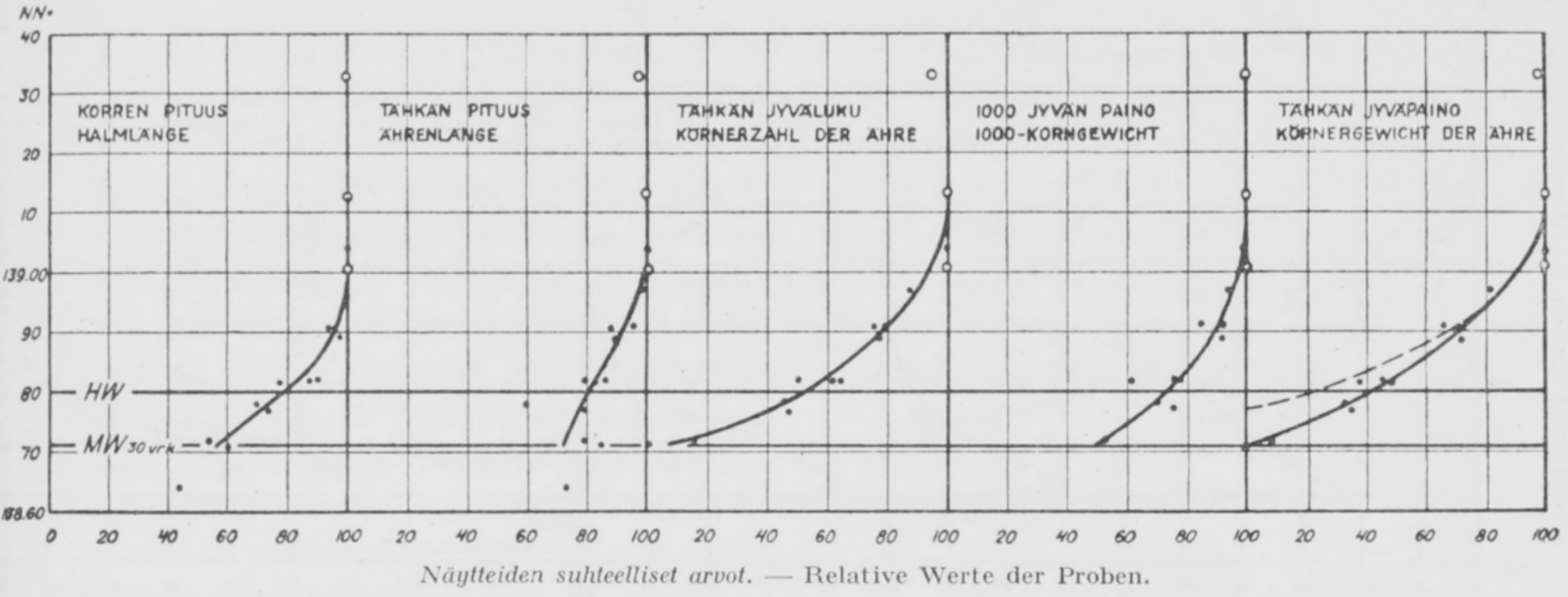

Piirros 2. RUKIIN morfologisten ominaisuuksien rippuvaisuus vedenkorkeudesta.

Fig. 2. Die Abhängigkeit der morphologischen Eigenschaften des ROGGENS vom Wasserstand.

määritetty 1000 j y vän paino. Täh k än j y väpain o on saatu jakamalla koko näytteen jyväpaino 20:1lä. Mittaustaulukoita ei tässä painatustilan säästämiseksi esitetä. Mainittakoon, että vahingoittumatonta viljaa vastaavat mittausarvot edellyttävät verraten voimakkaasti kehittynyttä kasvustoa.

Jotta voitaisiin käsitellä aineistoà suurempana kokonaisuutena, on maalaji-, lannoitus- ja lajike-eroavaisuuksien vaikutus eliminoitu pois siten, että sarjoittain kutakin morfologista ominaisuutta vastaava suurin mittausarvo on merkitty 100:ksi ja muut arvot on laskettu prosentteina tästä. Näiden arvojen perusteella on laadittu graafiset esitykset kasvupaikan korkeuden mukaan piirroksissa 2-4. Ne arvot, jotka ylöspäin siirryttäessä osoittavat kasvavaa suuntaa, on merkitty pisteillä $(\cdot)$, kun taas taitekohdan $(100 \%$ ) yläpuolella olevat arvot on kuvattu risteillä $(+)^{1}$, kuitenkin niin, että sarjan ylimmäinen arvo on merkitty ympyrällä

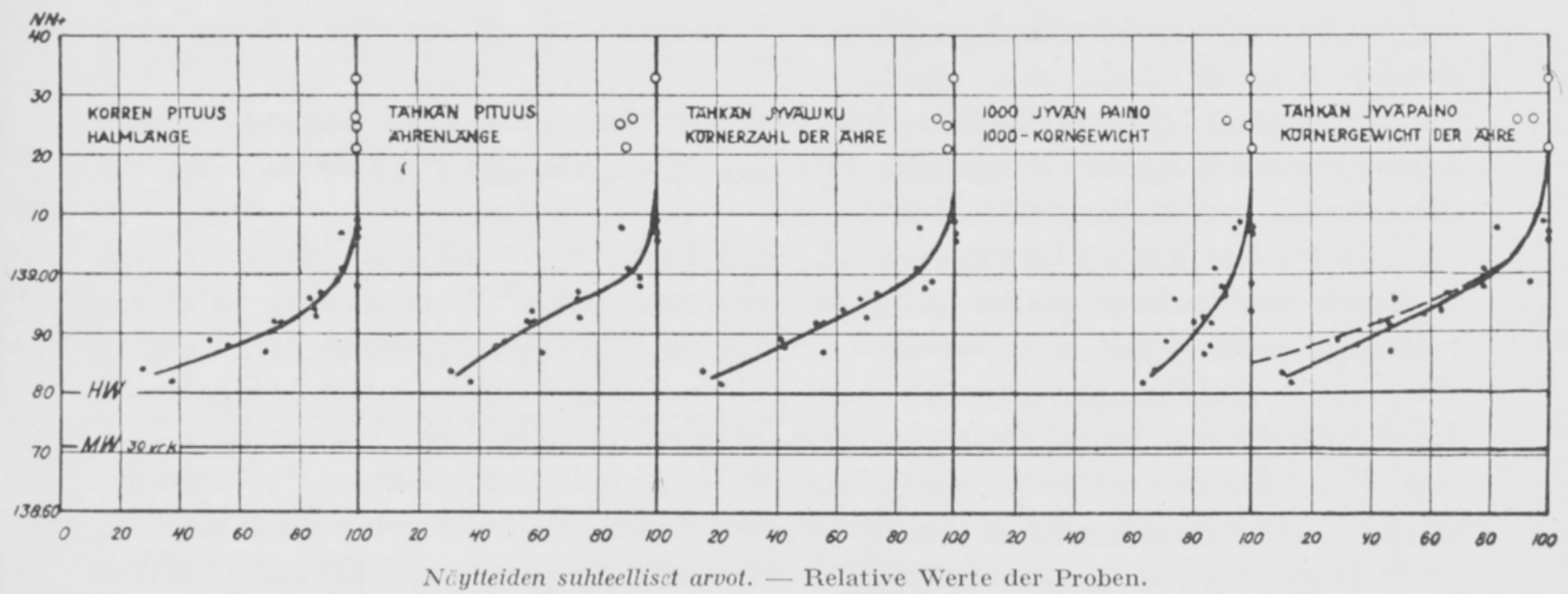

Piirros 3. OHRAN morfologisten ominaisuuksien rippuvaisuus vedenkorkeudesta.

Fig. 3. Die Abhängigkeit der morphologischen Eigenschaften der GERSTE vom Wasserstand.

1 Ilmenee vain kaurasarjoissa. 


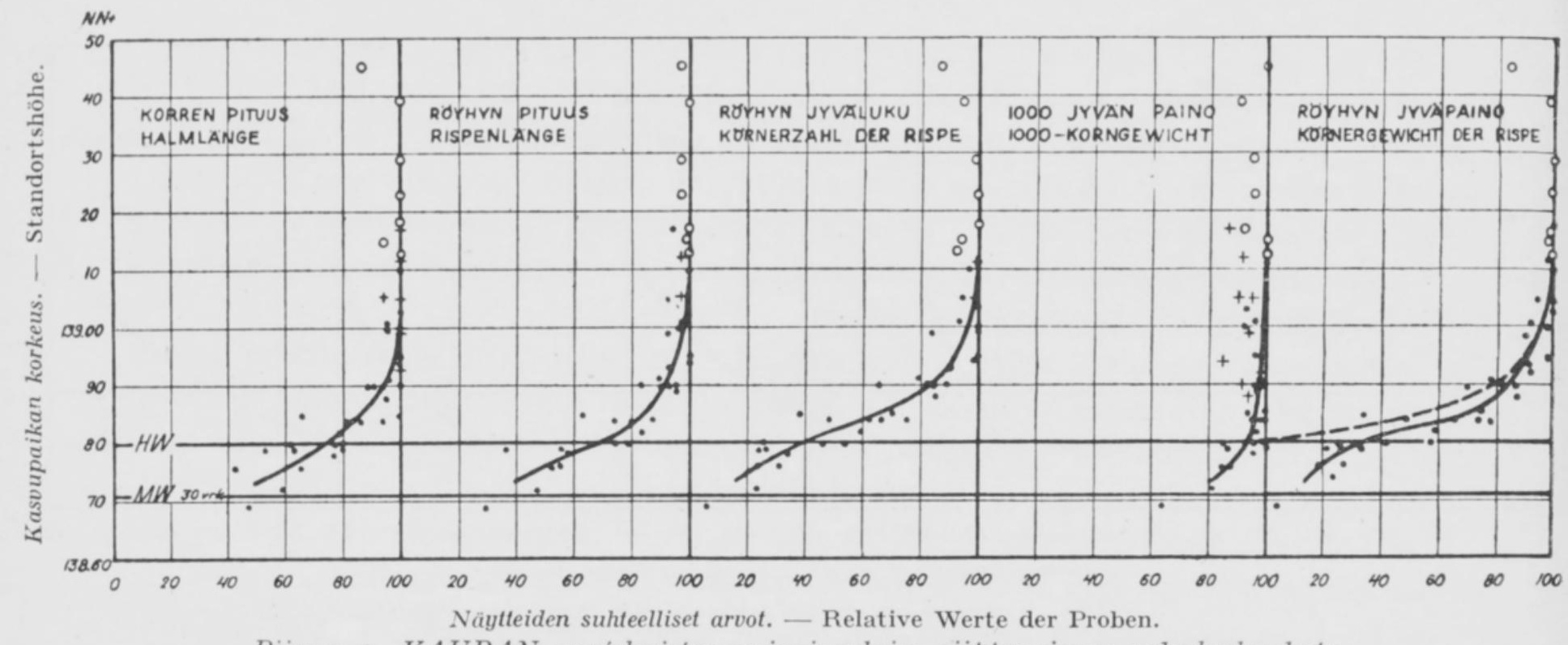

Piirros 4. KAURAN morfologisten ominaisuuksien riippuvaisuus vedenkorkeudesta.

Fig. 4. Die Abhängigkeit der morphologischen Eigenschaften des HAFERS vom Wasserstand.

(o), jolloin saadaan kuva eri sarjojen ylärajasta. Pisteryhmien kautta piirretyt käyrät osoittavat eri morfologisten ominaisuuksien riippuvaisuuden vedenkorkeudesta. Piirroksiin on merkitty myös vedenkorkeudet HW ja MW 30 vrk. Mainittakoon tässä yhteydessä, että MW 15 vrk. oli vain $2 \mathrm{~cm}$ HW:ä alempana.

Tärkasteltaessa k orren pitu utta koskevaa osaa pirroksissa 2-4, voidaan todeta, että rukiin ja kauran alimmat, suunnilleen MW 30 vrk:n korkeudella kasvaneet korret, jotka olivat seisseet vedessä n. 15 vrk., ovat pituudeltaan olleet $50-60 \%$ vahingoittumattoman viljan korsien pituudesta. Optimikorkeutta, siis korren pituuskasvun vahinkorajaa, vastaa näissä viljalajeissa suunnilleen 30 $\mathrm{cm}: \mathrm{n}$ kuivavara MW 30 vrk:sta ja $20 \mathrm{~cm}$ :n kuivavara HW:sta laskettuna. Ohralla ovat vahinkorajaa vastaavat kuivavarat $n .10 \mathrm{~cm}$ suuremmat, ja vähän $\mathrm{HW}: n$ yläpuolelta otetut näytteet osoittavat korren suhteelliseksi pituudeksi $30 \%$. Ohran huonompi vedenkestämiskyky rukiiseen ja kauraan verrattuna ilmenee siis tässä selvästi.

Tähkän pituudessa on havaittavissa suunnilleen samansuuruinen suhteellinen vesivahinko kuin edellä, mikä onkin luonnollista, kun vastaava kehitysaika on osa korren kasvamiskaudesta.

Tähkän jyväluvussa yliveden haitallinen vaikutus ilmenee paljon voimakkaammin kuin korren ja tähkän pituuskasvussa. Tämä koskee varsinkin ruista, ja ero johtunee kevätviljoihin verrattuna kasvuaikaan nähden eriaikaisesta ylivedestä. Rukiissa ylivesi sattui näet vain n. kaksi viikkoa ennen heilimöintiä. Kukkimisaikanaan kasvit ovat nimittäin verraten arat liialliselle kasvupohjan kosteudelle. Yliveden sattuessa rukiin korsi oli sitäpaitsi kerinnyt kasvaa jo verraten pitkäksi. Ne rukiin korret, jotka olivat olleet veden alla n. 15 vrk., olivat melkein jyvättömiä. Kaurassa niitä oli samalla korkeudella jonkin verran enemmän. HW:n korkeudella oli rukiin tähkässä jyviä $50 \%$ ja kauran röyhyssä $40 \%$ optimimäärästä. Rukiin ja ohran optimikorkeutta vastaa n. $40 \mathrm{~cm}: \mathrm{n}$ ja kauran n. $35 \mathrm{~cm}: \mathrm{n}$ kuivavara MW 30 vrk:sta. 
1000 jyvän painossa vesivahinko on suhteellisesti pienempi kuin edellä. Varsin selvästi tämä ilmenee kaurassa, jossa HW:n yläpuolelta mitatut näytteet osoittavat 1000 jyvän painoksi yli $90 \%$ suhteellista arvoa (risteillä merkityt pisteet on rinnastettava $100 \%: n$ arvoihin). Tämä merkitsee sitä, että kasvuajan alkupuolella huomattavastikin vesivahinkoa kärsinyt kasvusto kykenee muodostamaan verraten normaalisuuruisen jyvän, kun kuivatussuhteet ovat hyvät kypsymiskautena. Rukiissa ja ohrassa on 1000 jyvän paino HW:n korkeudella olevissa näytteissä n. $60-70 \%$ optimista.

Koska jyvän suhteellinen koko ei kovin suuresti muutcunut kuivavaran suuretessa, on t äh kän jy väpainoa esittävä käyrä suunnilleen samanmuotoinen kuin jyvälukua kuvàava. Näin on asian laita varsinkin kauran suhteen. Mikäli kasvutiheys olisi sama eikä korren pituuskaan osoittaisi merkittävää vaihtelua eri korkeuksilla, kuten tilanne on yliveden sattuessa vasta kypsymiskaudella, osoittaisi jyväpainokäyrä samalla eri korkeuksilta saatua s u h t e e 11 is t a s a t o a ja siis

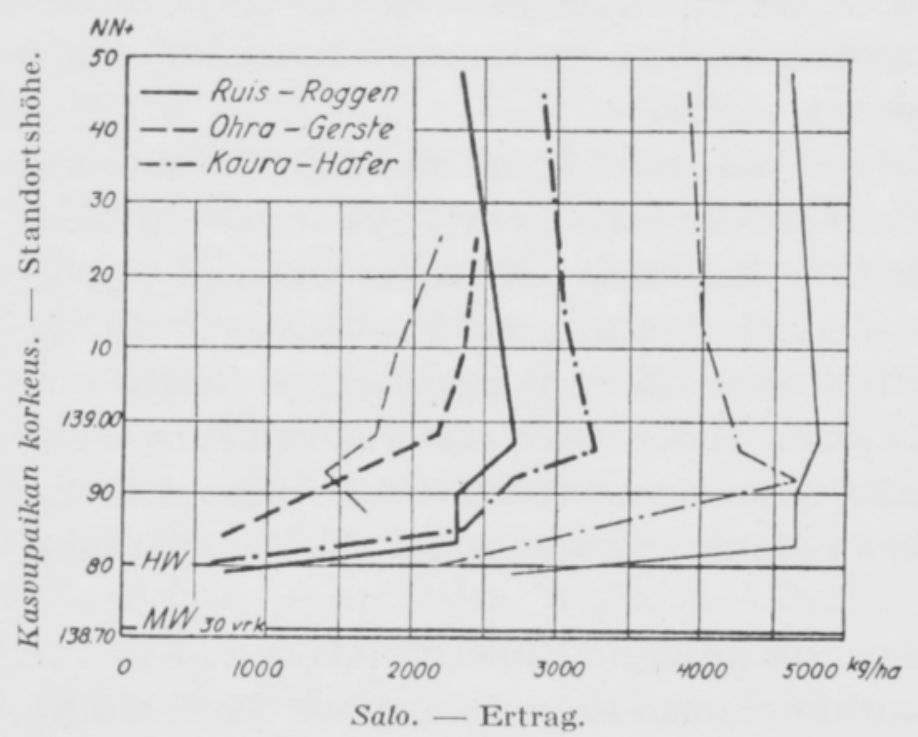

Piirros 6. Koealojen satotulokset. Paksulla viivalla piirretyt murtoviivat esittävät jyväsatoa, ohuella piirretyt olkisatoa.

Fig. 6. Die Ertragsergebnisse der Versuchsflächen. Die dick gestrichelten Linien stellen den Kornertrag, die dünn gezeichneten den Strohertrag dar.

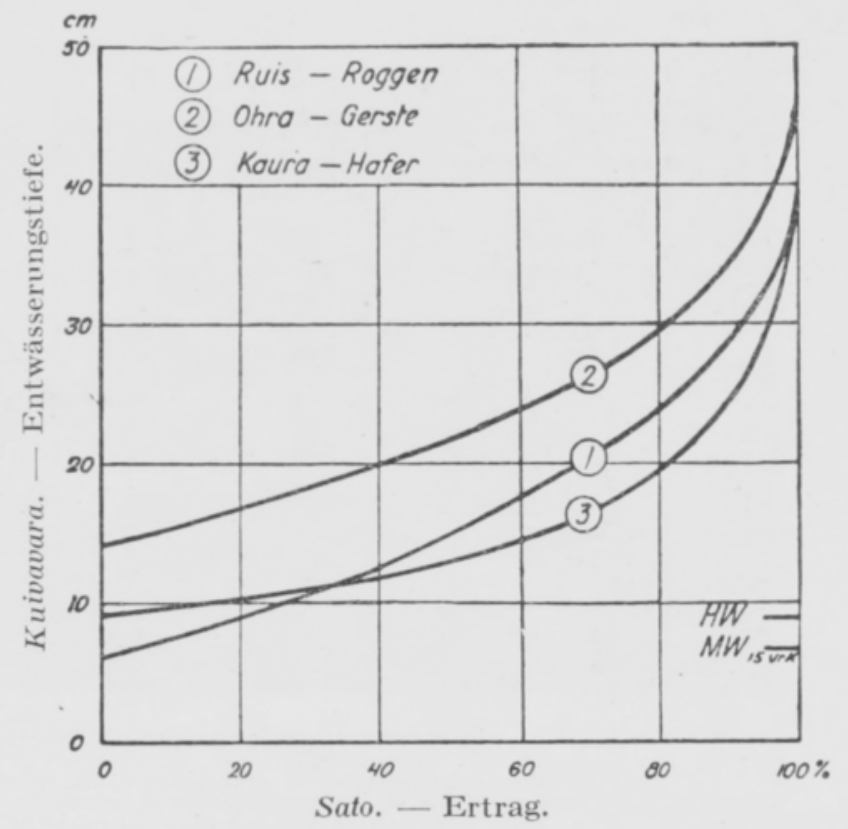

Piirros 5. Sadon riippuvaisuus vedenkorkeudesta kesällä I945. Määräävänä vedenkorkeutena (O-taso) 30 vrk, kestävän (8. VI.7.VII) ylivesikummun keskivesi (MW 3o vrk.). Fig 5. Die Abhängigkeit des Ertrages vom Wasserstand im Sommer 1945. Massgebender Wasserstand (0-Niveau) das Mittelwasser des 30 tägigen (8. VI-7. VII) Hochwassergipfels. myös aiheutuneen vesivahingon suuruutta. Kuten edeltä esitetystä on ilmennyt, kasvuston harventumista oli todettavissa yliveden läheisyydessä. Näin ollen tähkän jyväpaino on eräänlainen rajakäyrä, joka osoittaa syntyneen vesivahingon minimiarvon. Sitä rajaa, missä kasvusto oli jo yhtä tiheätä kuin ylempänä, kuvaavat parhaiten taulukossa 1 esitetyt silmävaraisesti arvioidut eri lajien vahinkorajojen korkeudet, joiden rajojen määrittelyssä kasvutiheys on ollut määräävänä perusteena. Tämä raja on rukiissa keskim. korkeudella 138.94, kaurassa 138.98 jà ohrassá 139.02. Korren pituuskäyriä tarkastelemalla voidaan todeta, ettei olkisadoissakaan näiden 


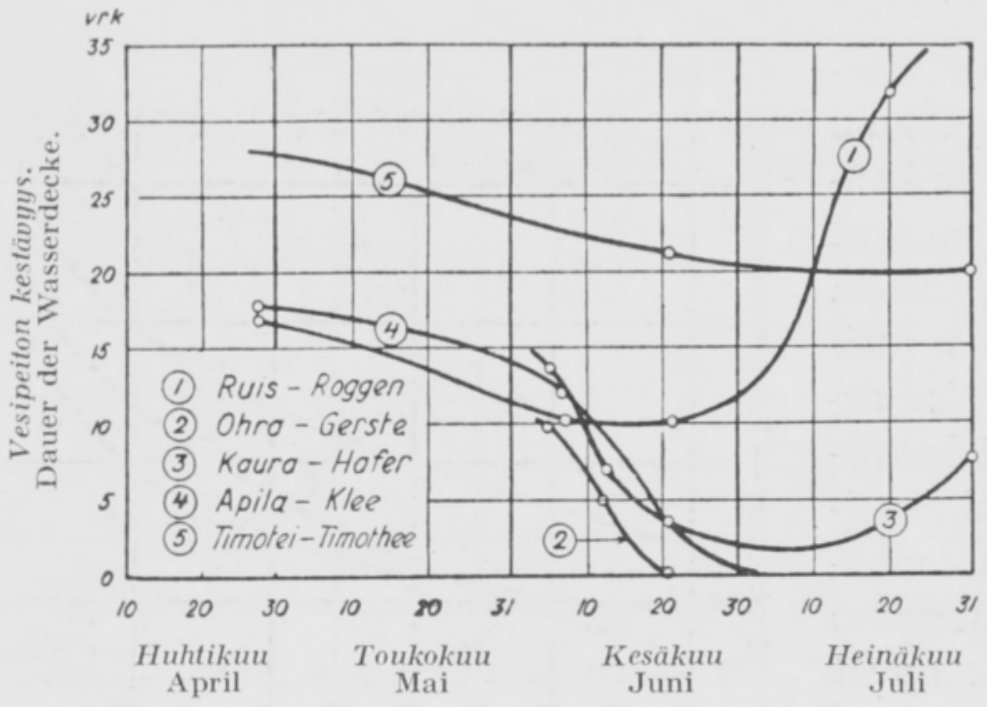

Piirros 7. Eri viljelyskasvien tuhoutumisrajoja vastaavat vesipeiton kestävyysajat kasvukauden aikana.

Fig. 7. Die den Abgangsgrenzen der verschiedenen Kulturpflanzen entsprechenden Zeiträume der Wasserdecke in der Vegetationsperiode. rajojen yläpuolella ole enää merkittäviä eroavaisuuksia eri korkeuksilla. Toisaalta on tehty erikseen havainnot eri lajien tuhoutumisrajoista (vrt. taulukko 1), joiden korkeuksien alapuolelta saatavilla sadoilla ei ole katsottu olevan käytännöllistä merkitystä. Jos piirretään käyrät, joiden 0 -pisteet ovat näin tiettyjen tuhoutumisrajojen korkeuksilla ja jotka tähkän jyväpainokäyrän yleistä muotoà seuraten yhtyvät näihin käyriin edelläesitettyjen vahinkorajojen korkeuksilla, saadaan jo verraten

tarkka kuva haitallisen vedenkorkeuden eri viljalajeille aiheuttamasta sadonvähennyksestä ko. kesänä. Näin piirretyt käyrät on merkitty katkoviivana piirroksiin 2-4, ja lisäksi ne on esitetty suhteellisina käyrinä vedenkorkeuteen (MW $30 \mathrm{vrk}$ ) verrattuna piirroksessa 5. Todetaan, että rukiin tuhoutumisrajaa vastaa $6 \mathrm{~cm}$ :n kuivavara (10 vrk. kestänyt vesipeitto), kauran $9 \mathrm{~cm}$ ja ohran $14 \mathrm{~cm}$. Rukiista on saatu $50 \%$ :n sato kuivavaran ollessa $15 \mathrm{~cm}$, kaurasta vastaavasti 13 $\mathrm{cm}: n$ ja ohrasta $22 \mathrm{~cm}: n$ kuivavaralla. Vahinkoraja on jyviin kohdistuvien tutkimusten perusteella noussut jonkin verran korkeammalle kuin maastossa silmävaraisesti tehdyt havainnot osoittivat. Se on rukiissa ja kaurassa vajaa $40 \mathrm{~cm}$ ja ohrassa $45 \mathrm{~cm}$ MW 30 vrk:n yläpuolella. Verrattuna HW:een vastaavat kuivavarat ovat 9 $\mathrm{cm}$ ja MW 15 vrk:een verrattuna $7 \mathrm{~cm}$ pienemmät.

Ohra osoittautuu siis, kuten yleisesti on tunnettua, viljalajeista suurinta kuivatusta vaativaksi. Rukiin ja kauran vedenkestämiskyky näyttää olevan tässä verraten samánlainen. Vertailua rajoittaá kuitenkin niiden eriaikainen kasvuaika. Mikäli halutaân selittää syitä näiden käyrien pieneen muotoeroavaisuuteen, voitaneen kiinnittää huomiota $\mathrm{mm}$. siihen, että rukiin voimakkaampi juuristo on kestänyt paremmin vesipeittoa kuin kauran. Siihen taas, että rukiin käyrä osoittaa korkeammilla kasvupaikoilla vähän suurempaa vesivahinkoa kuin kauran, lienee vaikuttamasssa se, että kasvuaikaăn nähden ylivesi sattui rukiille epäedullisemmin kuin kauralle.

On pantáva mieleen, että edellä esitetty koskee tilannetta, jolloin vedenpinta oli varhaiskeväällä alhaalla ja ylivesi sattui n. kuukausi kauran kylvön jälkeen sekä rukiin kasvuaikaan verrattuna n. kaksi viikkoa ennen heilimöintiä. Samalla on huomautettava, että havainnot koskivat keksinkertaista tiiviimpiä maalajeja ja että maanpinta oli sateiden johdosta verraten kosteaa.Viimeksimainittua osoittanee sekin, ettei havainnoissa voitu todeta yliveden edullista kostuttavaả vaikutusta, jollaista ilmeni varsin selvästi Saimaan rantapelloilla kesällä 1938 suoritetuissa tutkimuksissa. 
Maalajien - lähinnä kivennäismaan ja turvemaan vaikutuksesta olisi mahdollisuus tehdä eräitä vertailuja kaurasarjojen nojalla, joista neljä koski turvemaita. Koska havaintoja edustavat pisteryhmät piirroksessa 4 eivät kuitenkaan osoita kovin suurta hajontaa, niin ei tähän, ottaen huomioon vielä aineiston suppeudenkin, ole ryhdytty. Mainittakoon tässä yhteydessä, että usein kuullaan perusteltavan turvemaiden pienempää kuivatuksen tarvetta kivennäismaihin verrattuna sillä, että ensiksi mainituilla todetaan pellon alaraja usein suh-

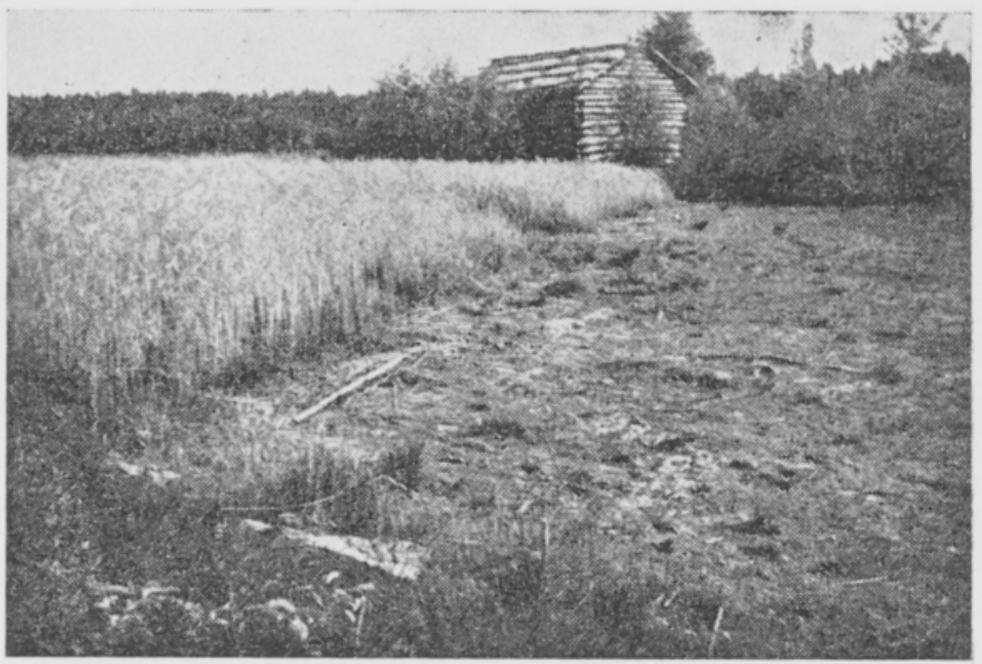

Kuva I. Selväpiirteinen tuhoutumisraja hiesupitoisella ohrapellolla $6 \mathrm{~cm} H W: a ̈$ korkeammalla. HW on ollut kuvassa näkyvien kaisla- ja ruokojätteiden korkeudella sekä viljelyksen alaraja korkeudella 138.40. Aallokko on liettänyt maanpintaa tuhoutumisvajan alapuolelta, minkä vuoksi se on kasvuton. Valok. I4. VIII. 45. Kaikki valokuvat paitsi kuva 6 on otettu Pirttijärven rannalta. teellisesti alemmaksi kuin kivennäismailla. Tämän oletan kuitenkin johtuvan pääasiassa turvemaiden j̣atkuvasta maanpinnan painumisesta niiden ollessà vuodesta vuoteen muokkaustöiden alaisena.

4. Koealoiltá suoritetut sadonmääräykset. Jotta saataisiin selvitystä siihen, minkä suuruista satoa tutkimusaineisto suunnilleen edusti, ja erääksi vertailuksi ko. tutkimusmenetelmän käyttökelpoisuudesta suoritettiin eräällä viljelysalueella, missä rinnakkaisilla saroilla ruis, ohra ja kaura olivat joutuneet yliveden vahingoittamaksi, sadonmääräykset eri korkeudella sijaitsevilta $1 \mathrm{~m}^{2}:$ n suuruisilta koealoilta. Rukiin (maatiainen) ja ohran (Vega) koealoja oli kumpiakin 5, kauran (Kytö) 6. Ensiksi mainitut korjattiin 15. VIII ja viimeksimainitut 27. VIII. Koealat olivat suorakaiteen muotoiset $(0.5 \times 2.0 \mathrm{~m})$ ja poikittain suurinta kaltevuutta vastaan, jolloin koealan korkeudenvaihtelut saatiin mahdollisimman pieniksi. Koealat vaakittiin $0.5 \mathrm{~m}: \mathrm{n}$ ruutuihin ja niiden keskikorkeus on laskettu painollisesti. Maalajina oli hyvässä kasvukunnossa oleva hietasavimaa. Vilja korjattiin sirpillä, sato kuivattiin ulkona ja puitiin käsin. Tutkimustulokset on esitetty piirroksessa 6 . Rukiista on saatu paras jyväsato - se vastaa $2720 \mathrm{~kg} / \mathrm{ha}^{1}$ - koealalta, jonka keskikorkeus on 138.97. Kauran paras jyväsato $3270 \mathrm{~kg} / \mathrm{ha}$ on saatu suunnilleen samalta korkeudelta. Ohran suurin jyväsato $2490 \mathrm{~kg} / \mathrm{ha}$ on ylimmältä koealalta. Alimpien koealojen jyväsadot ovat eri lajeilla n. $700 \mathrm{~kg} /$ ha. Rukiin olkisato on n. 2 kertaa ja kauran n. 1.3 kertaa suurempi kuin jyväsato. Ohralla on olkisato jyväsatoa vähän pienempi. Tulosten tarkastelu osoittaa, että edellä esitetyt vahinko- ja tuhoutumisrajojen korkeudet näyttävät

1 Edellyttää salaojitettua maata. 


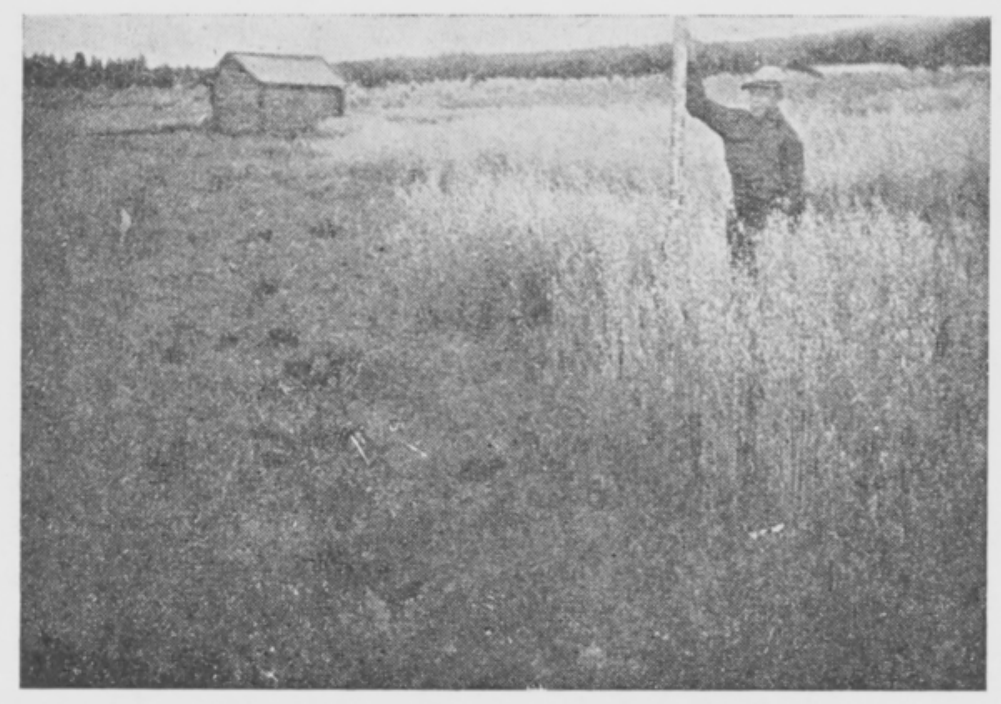

Kuva 2. Kaura turvemaalla, jossa tuhoutumisraja on suunnilleen $H W: n$ korkeudella (latta). Viljelyksen alaraja on ollut tätä korkeutta n. $30 \mathrm{~cm}$ alempana. Valok. 29. VIII. 45.

tulleen tämän mukaan riittävän korkealle arvioiduiksi. Laskettaessa suhteelliset sadot suurimpaan satoarvoon verrattuna, kuten edellä esitetyssä tutkimuksessa on tehty, ja verrattaessa niitä piirroksessa 5 esitettyihin käyriin (selvyyden vuoksi niitä ei ole tähän piirretty) voidaan todeta, että koeàlojen käyrät kulkevat jonkin verran alempana jyvänmittausten antamia käyriä. Ero on suurin rukiissa. Kaurassa se on varsin vähäinen. Koeàlojen korjuun yhteydessä otettiin koealojen vierestä myös vastaavat tähkänäytteet. Naiden kahden tutkimusmenetelmän keskeinen suhteellisiin arvoihin perustuva tarkastelu osoittaa samantapaista tulosta kuin edellä.

On selvää, ettei näin niukan koealoilta saadun havaintoaineiston nojalla voida tehdä pitkälle meneviä johtopäätelmiä. Tällä on kuitenkin katsottava olevan merkitystä siinä, että se antaa tukea edellä esitetylle, maastossa helposti suoritettavalle tähkänäytteisiin perustuvalle tutkimusmenetelmälle ja osoittaa jyviin kohdistuvien mittausten käyttökelpoisuuden haluttaessa saada selvitystä haitallisen vedenkorkeuden aiheuttamasta suhteellisesta vesiváhingostá.

\section{Eri aikaisten tulvien vaikutuksesta kasvien vedenkestämiskykyyn.}

Seuraavassa tarkastellaan suoritettujen tutkimusten valossa kysymystä siitä, miten kasvien vedenkestämiskyky ja siis syntynyt vesivahinko on riippuvainen viljelyksille nousseen tulvan sattumisajasta.

KAITERA $(2,4)$ on kolmen vuoden aikana Tikkurilassa suorittamissaan upotuskokeissa tutkinut viljelyskasvien vedenkestämiskykyä kasvukauden alussa. Tähän aikaan sattuvatkin tulvat suurimmassa osassa vesistöjämme. Tutkimus koski ruista, ohraa, kauraa, apilaa sekä timoteita, ja tutkimukset oli järjestetty niin, että koeastiat upotettiin eri pitkiksi ajoiksi Keravanjokeen. Tavallisesti oli kaksi koe-erää, joiden upotus suoritettiin eri aikana. Rukiin aikaisin upotus tapahtui huhtikuun 17. p:nä v. 1934 ja ohran myöhäisin kesäkuun 13. p:nä v. 1935. Kasvien yksilöluku astiassa laskettiin ennen upotusta ja sen muuttumista samoinkuin koekasvien kehitystä seurattiin kypsymiseen saakka. Koetulosten perusteella on laadittu diagrammit, jotka osoittavat eri kasvilajien suhteellisen sadon suuruuden eri pitkiä upotusaikoja käytettäessä. Vesistöjen varsilla tehdyt havainnot tukevat astiakokeiden antamia tuloksia (3).

Kesäkuun loppupuolella, siis edellistä myöhemmin sattuvien tulvien vahin- 
gollista vaikutusta on edellä selostettu. Samantapaisen tutkimuksen on kirjoittaja suorittanut viljakasvien kasvuajan loppupuolella, heinä-elokuun vaihteessa sàttuneen tulvân aiheuttamasta vesivahingosta (5). Tässä tutkimuksessá on ollut lisäksi mahdollista, vedenpinnan ollessa viljakasvien kypsymiskauden alkuun saakka nouseva, tehdä vertailuja eri morfologisten ominaisuuksien riippuvaisuudesta vastaavien kehitysjaksojen vedenkorkeuksistá.

Ryhtymättä tässä yksityiskohtaisemmin selostamaan

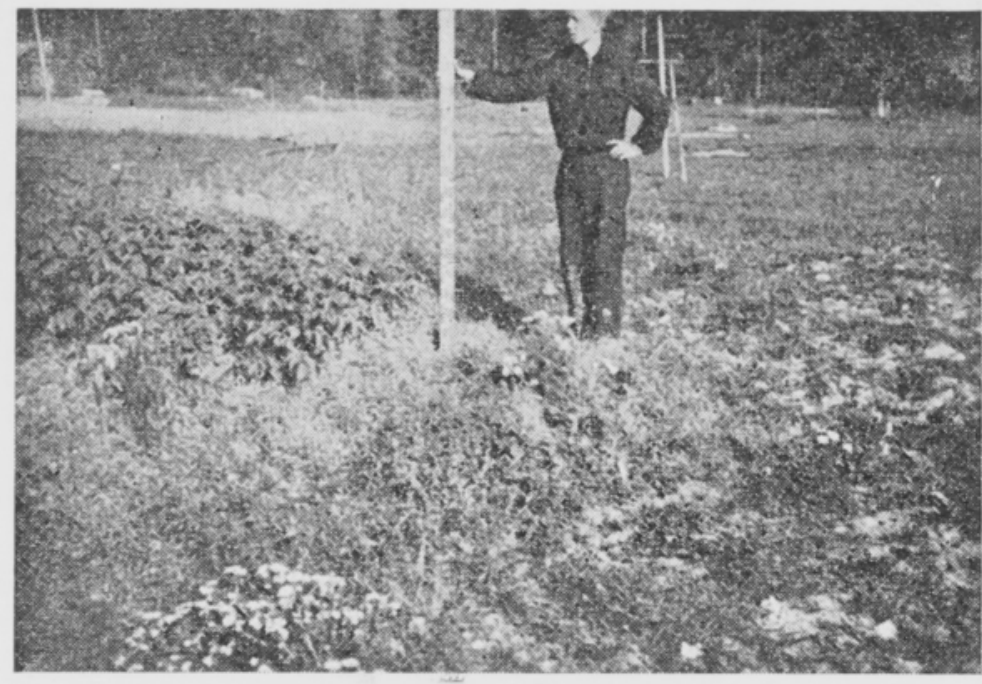

Kuva 3. Peruna savimaalla. Tuhoutumisraja on varsin selväpiirteinen to cm $H W: a ̈$ (latta) korkeammalla. Kuvassa on todettavissa kasvun voimistuminen kuivavaran suurentuessa. Vesi on tasoittanut vakoja ja liettänyt maanpintaa, johon on ilmestynyt jonkin verran rikkaruohoja. Taustalla on näkyvissä tuhoutunutta ohraviljelystä. Valok. I5. VIII. 45. ja vertailemaan eri tutkimuksià keskitetään niistä $\mathrm{t} u \mathrm{hout}$ u mis raja a koskevat tulokset kaaviolliseen esitykseen piirroksessá 7 , josta ilmenee, miten kauan eräät tärkeimmät viljelyskasvimme kestävät kasvukauden eri aikoina vesipeittoá, ennenkuin sato jää käytännöllisesti katsoen merkityksettömäksi. Esitysten laatimistavasta on mainittava, että KAITERAN tutkimuksissa on »käytännölliseksi» - siis muihin tutkimuksiin verrattavaksi - tuhoutumisrajaksi otettu $10 \%$ :n satotulos ja että käyriä määräävät pisteet (kuvaan ympyröillä merkityt) on sijoitettu yliveden (upotuksen) kestämisajan keskikohdalle. Tuhoutumisrajan asettuessa useita vuorokausia kestäneen ylimmän veden tasolle on vesipeittoa vastaavaksi ajaksi aaltoilun takia otettu puoli ylimmän veden kestävyysajasta. Upotusaikojen ollessá timotein upotuskokeissa liian lyhyitä, on sitä koskevat varhaiskevään ajat päätelty silmävaraisten hàvaintojen nojalla. On selvää, että piirroksen 7 mukainen vertailu on verraten ylimalkainen jà vain suuntaa osoittava, sillä osan tutkimuksista kohdistuessa Helsingin, osan Kajaảnin ja osan Joensuun ympäristöön eri mảantieteellinen asema ja erilaiset sääsuhteet aiheuttavat vaihteluja kasvuaikaan ja kasvien kehitykseen nähden. Ajan suhteen tapahtuviin tásoituksiin ei ole kuitenkaan tässä ryhdytty. Suurin piirtein esitys vastannee tilannetta, jolloin kaura kylvetään n. 15. V ja se kypsyy n. 25. VIII. Edellistä ehkä vielä merkitsevämpi, eri tutkimusten vertailukelpoisuutta rajoittava tekijä on se, että upotuskokeissa upotus on tapahtunut yht'äkkisesti, jolloin »kuivatus» ennen ja jälkeen upotuksen on ollut täydellinen. Kesäkuun 21. päivää vastaàvissa v. 1945 havàinnoissá on ylivesi kahden viikon aikana ollut suhteellisen tasainen, mutta sen kummallakin puolen on vedenpinnan nousu ja lasku ollut verraten jyrkkää. Sensijaan on elokuun 1. päivän ylivesi v. 1938 ollut erittäin pitkäaikainen, jolloin tuhoutumisrajojen korkeuteen on ollut vaikuttamassá enemmän kuin edellä lähellä maanpintaa olleen 


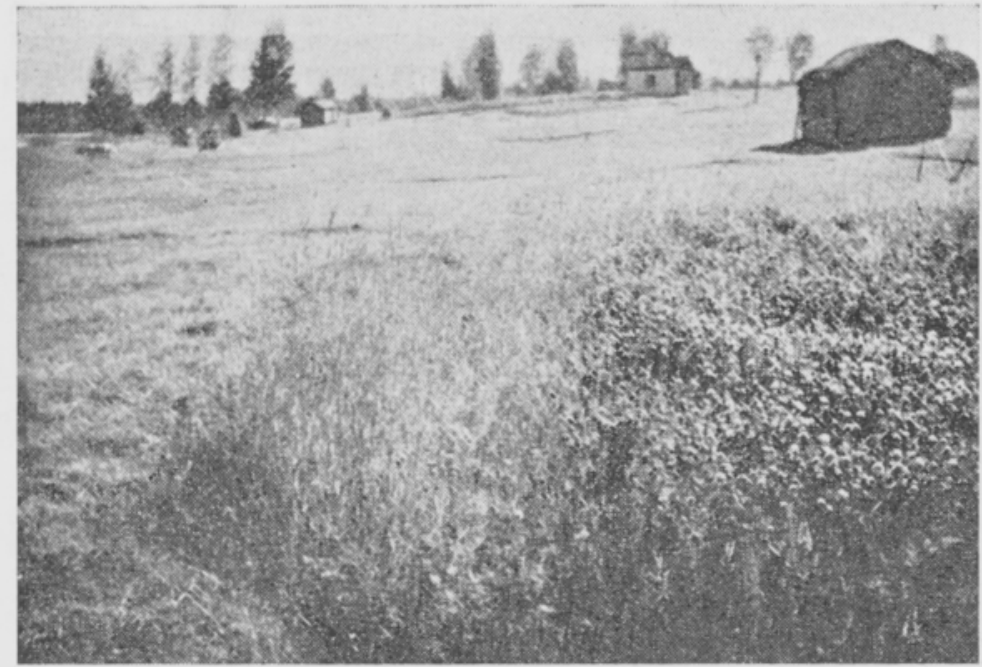

Kuva 4. Siemenheinäksi jätetty puna-apilavaltainen 2. vuoden nurmi hietasavimaalla, missä apilan tuhoutumisraja on erikoisen jyrkkä $H W: n$ korkeudella. Kuvan vasemmassa laidassa näkyvän viljelyksen alarajan korkeudella 138.68 ei timoteissa ole huomattavaa vesivahinkoa todettavissa. Valok. 6. VIII, 45. pohjaveden korkeus. Näin ollen käyrät osoittanevat alkukesästä ehkä hieman liiąn pitkiä vesipeiton kestäyysaikoja, kun taas kàsvukauden loppupuolella käyrissä on eräänlainen "varmuus». Sikäli tilanne vastaa suunnilleen luonnollisia olosuhteita, että vesistöissä tulvat ovat yleensä sitä lyhytaikáisempia, mitä aikaisemmin ne sattuvat. Silmävaraiset maastossa tehdyt havainnot osoittavat kuitenkin, ettei edellä esitetyillä seikoilla ole kovin merkittävää vaikutusta vertailutuloksiin.

Tårkasteltaessả piirrosta 7 voidaàn päätellä, että huhti-toukokuun vaihteessa, maan ollessa tällöin vielä roudassa, talvehtivat viljelyskasvit kestävät kuolematta yli kaksi viikkoà kestäneen vesipeiton alla ja että apilaa lukuunottamatta niiden vedenkestämiskyky on kesällä parempi kuin kevätviljojen. Tämä johtunee ensiksimainittujen voimakkaammàstá juuristostã. Viljelyskasveista timotein vedenkestämiskyky osoittautuu parrhaaksi, jà sen tuhoutumisrajaa vástaa koko kasvukauden ajan n. kolmen viikon ajan kestänyt vesipeitto. Rukiin jälkeen näyttäisivät järjestyksessä olevan kaura, apila ja ohra, vaikkakin niiden keskeinen suhde riippuu jonkin verran tulvàıı sattumisajasta. Yleisenä huomiona voidaan todeta, että viljakasvit ovat kesäkuun lopulla ja heinäkuun alussa arimmat maanpinnalle nouseville tulville. Tämä onkin ymmärrettävää, sillä suunnilleen tällöin alkaa jyvää tuottava kehitysjakso, ja jos haitallinen vedenkorkeus häiritsee tähkän kehitystä sekä kukkimista ja täten siis jyvien muodostumista, eivät myöhemmin parantuneet kuivatussuhteet voi syntynyttä vahinkoa enää korvata. Rukiin kehityksen ollessa aikaisempi kuin kevätviljojen sillä on tässä suhteessa kriitillisin aika ilmeisesti jo kesäkuun puolella. Apilá osoittautuu loppukesällä kestämättömäksi vesipeitolle, mihin lienee ainakin osittain vaikuttamassa lämmin järvivesi, joka mädännyttää helposti varsinkin niiton jälkeen matalaa åpilakasvustoa. Samanlaisia kasvuolosuhteita vastaavien apilan ja timotein keskeinen vertailu osoittaa, että viljelyskasvien luontainen vedenkestämiskyky voi olla kovin erilainen.

KAITERA (4) on havainnut, että pelloilla, joilla tulvat sattuvat varhain keväällä, on viljelyskasvien tuhoutumisraja epäselvä (4). SEPPÄNEN (6) on Oulujärven rantapelloilla todennut tuhoutumisrajan selväpiirteiseksi yliveden sattuessá kesäkuun loppupuolella. Samaa osoittavat myös edellä selostetut v:n 1945 tutkimukset. Vuonná 1938 Saimaan rantapelloilla tehdyistä tutkimuksista taas ilmenee, että viljakasvien kasvuajan loppupuolella maanpinnalle noussut tulvavesi ei muodosta 
viljelyksille selvää tuhoutumisrajảa (5). Edellä esitettyyn saa selvityksen tárkastelemalla, miten haitallinen vedenkorkeus on kasvuston kehitystä häirinnyt. Vertailtaessa KaITERAN huhtikuun 18. päivänä âloitettujen upotuskokeiden tuloksia voidaan todeta, että rukiin yksilöluku on 12 vrk. kestäneen upotuksen johdosta alentunut $25 \%$. Korren pituuteen ei upotus ole vaikuttanut, mutta tähkän pituus on pienentynyt $20 \%$ ja 1000 jyvän paino $9 \%$. Korjattu jyväsato on ollut $65 \%$ upottamattomien koeastioiden

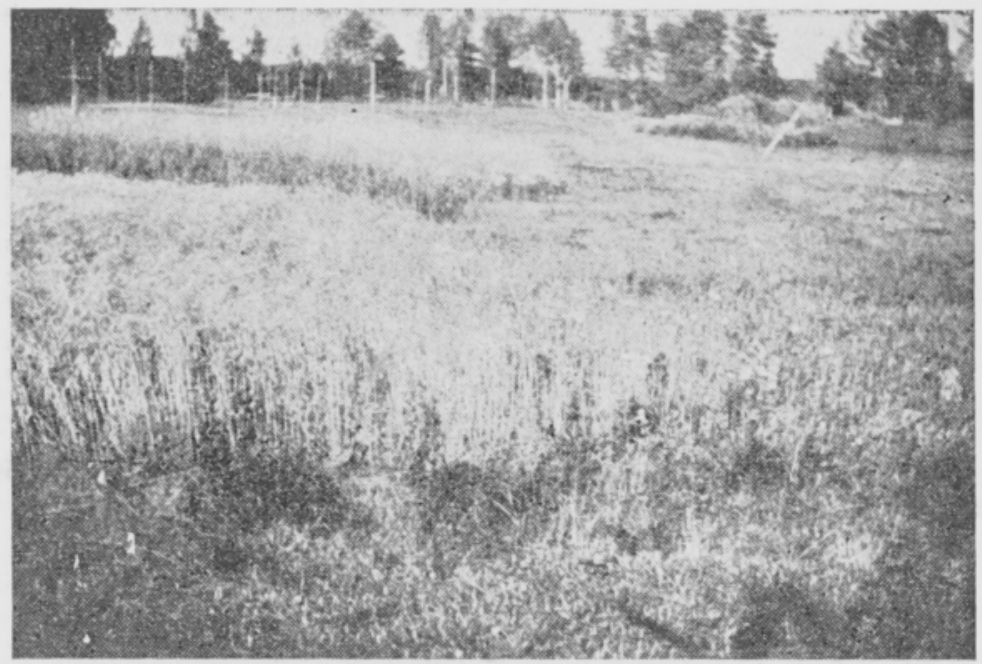

Kuva 5. Etualalla on näkyvissä ohra-ja taustalla ruissarka, joilta koealojen sadonmääritykset on suoritettu. Kuvassa näkyvä rikkaruohokasvillisuus — enimmäkseen päivänkakkavaa on pääasiallisesti ohran tuhoutumisrajan (I38.85) ja HW:n välisellä vyöhykkeellä. Valok. 6. VIII. 45 . sadoista. Yhtä kauan kestäneessä upotuksessả on apilàn yksilöluku vähentynyt $42 \%$ jả korjattu sato $21 \%$. Timoteissa ovat vastaavat arvot $38 \%$ ja $28 \%$, jolloin upotus on kuitenkin kestänyt 18 vrk. Edelläesitetty osoittaa, että vesivahinko ilmenee suurimmảksi osáksi siinä,että upotus on aiheuttanut heikoimpien yksilöiden kuolemisen ja siis kasvuston harventumisen, mikä merikitsee tuhoutumisrajan muodostumista epäselväksi. Kasvien kehitykseen ei varhain keväällä suoritettu upotus näytä vàikuttaneen kovinkaan haitallisesti. Niinpä upotuksen johdosta sato korjattua yksilöä kohden rukiissa on alentunut vain $15 \%$, mutta apilassā suurentunut $35 \%$ ja timoteissà 17 \%. Varsinkin apilassa on tähän ilmeisesti vaikuttanut kasvualân lisääntyminen yksilöä kohden. - Vuonna 1945 saattoi todeta, että ennen viljakàsvien tähkimisaikaa viljelyksille noussut tulvavesi tuhoaa kasvillisuuden verraten jyrkästi tietylle korkeudelle saakka, mutta aiheuttaa osittain myös kasvuston harrventumisen ja kasvun hidastumisen jonkin verran tämän kasvurajan yläpuolellekin. Varsin voimåkkaasti vesivahinko ilmenee tähkän jyväluvussa. Esitetyistä syistä tuhoutumisrája on luonnossá selvästi määriteltävissä. - Tulvan sattuessa vasta loppukesällä viljakasvit ovat orastuneet tásaisesti sekä kehittyneet jyvän kasvamisja kypsymisasteelle saakkà normaaleissa olosuhteissá, minkä vuoksi vesivahinko on todettavissa pääasiassa vain jyvien koosta. Niinpä v. 1938 voitiin todeta täysimittåista ruistá, jonka 1000 jyvän paino oli vain 40 \% optimiarvostá. Saman vuoden tutkimukset ovat osoittaneet, että viljakasvien korret kestävät tällöin verraten pitkäaikaista vesipeittoa. Tämän vuoksi ei pelloille muodostu selväpiirteistä tuhoutumisrajáa, ja se voidaankin määritellä vasta erikoistutkimusten avulla. Lisäksi tutkimukset ovat osoittaneet, että jyvän kypsyessä kasvit eivät ole enää niin arat liialliselle kasvupohjan kosteudelle kuin aikaisemmin. Siitä johtuu, että tuhoutumisraja asettuu tällöin suhteellisesti alemmaksi kuin aikaisemmin sattuvan tulvan vaikutuksesta. Niinpä v. 1938 rukiin arvioitu tuhoutumisraja 


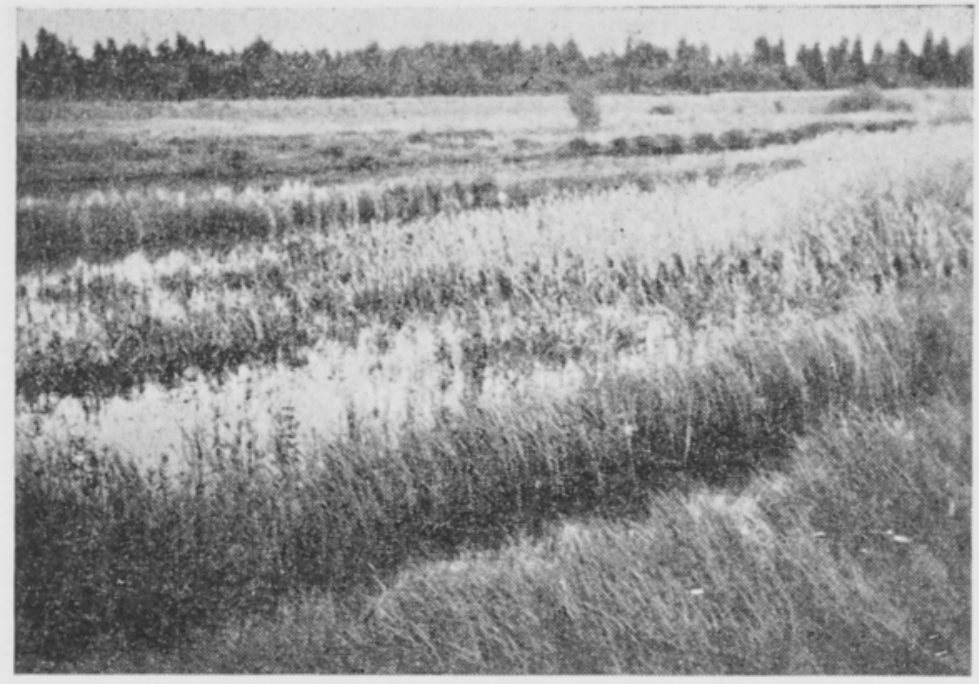

Kuva 6. Epämääräinen tuhoutumisraja kaurapellolla Saimaan rannalla kesällä I943, jolloin ylivesi sattui heinä-elokuun vaihteessa. Valok. 9. VIII. 43. (korkeus, jonka alapuolelta saatu sato suunnilleen vastási korjuukustannuksia) edellytti n. 30 vrk. kestävää vesipeittoa. - Voidaan siis todeta, että viljakasveissa tulvan vahingollinen vaikutus on todettavissa pääasiassa vain sen kásvinosan muodostumisessa, jonkà kehitys on voimakkaimmillaan tulvan sattuessa.

Havainnoista käy ilmi, ettei maảlaji- ja sääsuhteilla ole merkittävää vaikutusta tuhoutumisrajan korkeuteen. Tämä onkin ymmärrettävää varsinkin silloin, kun tuhoutu-

misraja muodostuu ylimmän veden alapuolelle tai sen välittömään läheisyyteen.

V a h i n k or a ja n määritteleminen on paljon epämääräisempi kuin tuhoutumisrajan sikäli, että vahingon suuruus on vähäinen vahinkorajan läheisyydessä, ja on vaikea arvioida, missä se käytännöllisesti katsoen päättyy. Sen korkeuteen vaikuttavat sitäpaitsi jo varsin merkittävästi maảlaji- ja sääsuhteet, minkä vuoksi näiden vaikutuksen selvittämiseksi vaaditaan monivuotiset kenttäkokeet. Maataloushallituksen vesiteknillisissä tutkimuksissa onkin kiinnitetty erikoista huomiota tämän kysymyksen selvittämiseen suorittamálla pitkäaikaisia pohjavesipadoksia. Puuttumatta tämän vuoksi laajemmin tähän kysymykseen mainittakoon vain, että v. 1938 ja v. 1945 kirjoittajan suorittamissa tutkimuksissa viljakasvien vahinkoràja àsettui $n .25-35 \mathrm{~cm}$ kesän ylimmän veden yläpuolelle - nurmikasveilla hieman alemmaksi sekä perunalla ja juurikasveilla ylemmäksi. KAITERA (3) on havainnut vahinkorajan olevan vain vähän yläpuolella ylintä vettä tulvan sattuessa varhain keväällä. HALLAKORPI (1) on esittänyt, että peltoviljelyksessä voidaan vahinkoraja arvioida $0.1 \mathrm{~m}$ ylemmäksi ylintä vettä sen sattuessa lyhytaikaisena varhain keväällä maan ollessa vielä roudassa ja $0.3 \mathrm{~m}$ ylemmäksi ylintä vettä sen sattuessa kevättyökauden alkupuolella tai kevättyökauden jälkeen. Tämä saa siis vahvistusta edellä esitetyistä havainnoista.

Vielä huomautettakoon, että vaikka viljakasvit keskellä kasvuaikaansa ovat arimmat kestämään maanpinnalle noussutta vesipeittoa, ei se aina merkitse sitä, että myös vahinkoraja olisi tällöin korkeimmalla. Kasvien lisäkasvu on nimittäin ennen tähkälle tuloa voimakasta ja vedenkäyttö tämän vuoksi suurtá, minkä vuoksi poutákesänä vahinkoraja voi tänä aikana asettuà suhteellisen âlas.

Edellä on ilmennyt, että tuhoutumis- ja vahinkorajan korkeus on riippuvainen paitsi kasvilajista myös tulvan sattumisajasta ja kestävyydestä. Maalajilla on myös vaikutuksensa varsinkin vahinkorajan korkeuteen. Laadittaessa suhteellista satoa ja vedenkorkeuden keskinäistä suhdetta kuvaavia käyriä — s a t o- 
k ä y ri ä - on näihin kaikkiin tekijöihin kiinnitettävä huomiota. Käyrien 0kohdan määrännee pääasiallisesti ylin vesi, kun taas sen yläosan ja yleisen muodon on katsottava olevan riippuvainen pitempiaikaisesta vedenkorkeudestá. Määräävänä vedenkorkeutena voitaneen pitää 15 vrk:n tai mahdollisesti pitemmänkin ajan kestävän ylivesikummun keskivettä. Vaikkakin ko. kasvilajia vastaava tuhoutumisraja edellyttäisi jonkin ajan kestävää vesipeittoa, ei käyrän 0-pistettä ole syytä ulottáa ylimmän veden alapuolelle, sillä veden kuljettamat kaislajätteet, maanpinnan liettyminen sekä aallokon vaikutus tekevät ylimmán veden alapuolella olevalta vyöhykkeeltä saatavan sadon epävarmaksi.

Käytännön sovellutuksissa tullaan useastikin toimeen "yleiskäyrällä», joka vastaá keskimääräisiä kàsvilaji- ja vedenkorkeussuhteita. Haluttaessa kuitenkin tarkempaa selvitystä vedenkorkeusvaihteluiden vaikutuksesta rantamaiden viljelykseen tarkastelu on tehtävä vuosittain kulloinkin vallinneiden vedenkorkeuksien mukaan eri viljelyskasvien tai ainakin vilja-, nurmi- sekä peruna- ja juurikasvien osalta, jolloin kullekin kasviryhmälle on määrättävä omat satokäyrät, joiden muodossá on mikäli mahdollista otettàvà huomioon vielä yliveden sattumisaiká.

Eri viljelyskassvien vedenkestämiskyvyn tunteminen on suureksi hyödyksi myös màan kastelua, lähinnä pohjavesipadotuksia ja upotuskastelua toimeenpantaessà. Tällöin voidaân päätellä, miten eri kasvien viljelyssuhteet olisi padotusalueella parhaiten järjestettävä ja mitkä kasvit tulevat määräämään upotuksen kestämisajan.

Säännöstelyhankkeisiin liittyviä maatalouden hyödyn- ja vahingonarvioita laadittaessa on erittäin keskeiseksi tullut kysymys kasvien vedenkestämiskyvyn muuttumisesta kassvukauden aikana. Säännöstelyissä pyritään nimittäin alentamaan alkukesän korkeita tulvahuippuja ja siirtämään ne tasoitettuina myöhäisemmiksi, jolloin kasvuâ määräävä vedenkorkeus sattuu myöhemmin kesällä. Riittävän selvyyden saamiseksi säännöstelyn viljelyksille aiheuttamasta hyödystä tai vahingostá on tunnettava määräävän vedenkorkeuden sattumisajan ja sen kestävyyden vaikutus satokäyrien muotoon.

KIRJALLISUUTTA - SCHRIFTTUM.

(1) Hallakorpi, I. A., Perusparannusten arvioiminen ja kustannustenjako maankuivatusyrityksissä. Helsinki 1932.

(2) Kaitera, Pentti, Viljelyskasvien kyvystä kestää vesipeittoa, Maataloustieteellinen aikakaushirja, 7. vuosik. Helsinki 1935.

(3) —- Vedenkorkeusvaihteluiden vaikutuksesta rantamaiden pelto- ja niittyviljelykseen, Maataloushallituksen vesiteknillisiä tutkimuksia 3, Helsinki 1941.

(4) - - Maataloushallituksen vesiteknillisissä tutkimuksissa suoritetuista vesivahinkokokeista. Maanviljelysinsinööriyhdistyksen vuosikirja 1941. Helsinki 1941.

(5) Saukкo, Pentti, Saimaan rantapelloilla suoritettuja viljelyskasvien vesivahinkotutkimuksia, Maataloushallituksen vesiteknillisiä tutkimuksia 4, Helsinki 1946.

(6) Seppänen, Eino, W. Peltoviljelyksen vaatimasta kuivatussyvyydestä, Maanviljelysinsinööriyhdistyksen vuosikirja 1940, Hämeenlinna 1941. 


\title{
REFERAT.
}

\section{ÜBER DIE WASSERRESISTENZ VON KULTURPFLANZEN.}

\author{
Pentti Saukko.
}

\author{
Amtsstelle der Saimaaregulierung, Helsinki.
}

In der Studie wird berichtet über die Untersuchungen, die im Sommer 1945 auf den Uferkulturen der zum Gewässergebiet des Oulujoki gehörenden Seen Pirttijärvi und Nuasjärvi ausgeführt worden sind über den Schaden, der den Kulturpflanzen durch das gegen Ende Juni eingetretene Hochwasser verursacht worden ist. Die Wasserstands- und Niederschlagsverhältnisse sowie die durchschnittlichen Wachstumszəiten im Untersuchungsgebiet sind in Abb. 1 wiedergegeben. Ausser den augenscheinlichen, die Schaden- und Abgangsgrenzen der verschiedenen Pflanzen angehenden Nivellierungen, deren Mittelwertergebnisse aus Tabelle 1 hervorgehen, sind den verschiedenen morphologischen Eigenschaften der Getreidepflanzen zugewandte Untersuchungen auf Grund von Ähren(Rispen-)proben aus den Kulturen ausgeführt worden. $\mathrm{Zu}$ jełer Probe haben 20 Ähren gehört. Die einer Probe entsprechenden Messungswerte sind in relative Werte umgerechnet und auf ihrer Grundlage graphische Darstellungen ausgearbeitet worden zu den Figuren 2-4, die also die Abhängigl eit der verschiedenen morphologischen Eigenschaften vom Wasserstand widerspiegeln. Ausserdem sind auch für $1 \mathrm{~m}^{2}$ grosse Probeflächen Ertragsbestimmungen ausgeführt worden, deren Ergebnisse aus Abb. 6 hervorgehen.

Die Untersuchungen lehren, dass die Abgangsgrenze sich bei den verschiedenen Kulturpflanzen recht deutlich abhebt. Unter den Kulturpflanzen hat sich der Timothee in der Wasserresistenz als am besten erwiesen. Seiner Abgangsgrenze hat eine etwa 20tägige, der des Leins eine 14tägige und der des Roggens eine 1ltägige Wasserdecke entsprochen. Die Abgangsgrenze von Hafer und Klee hat in der Hochwassergrenze gelegen, die der Gerste wiederum $3 \mathrm{~cm}$ und die der Kartoffel $10 \mathrm{~cm}$ höher. Die Schadengrenze hat sich bei den Wiesenpflanzen schwer festlegen lassen. Sie hat sich wenigstens nicht viel höher als die Abgangsgrenze hingezogen. Bei den übrigen Pflanzen hat die Schadengrenze durchschnittlich etwa $30 \mathrm{~cm}$ oberhalb der Abgangsgrenze gelegen. Der Wasserschaden äussert sich bei den Kulturpflanzen teilweise als Lichtung des Bestandes, sehr stark aber auch als Minderung der Anzahl der in der Ähre enthaltenen Körner. Auf die Korngrösse hat das Hochwasser verhältnismässig wenig eingewirkt. Auf Grund der Untersuchungen sind die Kurven in Abb. 5 gezeichnet, die für den betreffenden Sommer die relativen Erträge von Roggen, Gerste und Hafer im Vergleich zum Mittelwasser des 30tägigen Hochwasserstandes zeigen. Es sei bemerkt, dass der grösste Teil der Beobachtungen Sandtonböden betroffen hat und dass der Boden bei eintretendem Hochwasser infolge der reichlichen Niederschläge verhältnissmässig feucht gewesen ist.

Früher sind Untersuchungen über die Wirkung der am Anfang und am Ende der Vegetationszeit eingetretenen Hochwasser auf die Kulturen ausgeführt worden. Auf Grund dieser drei verschiedenen Zeitpunkten entsprechenden Untersuchungen ist in Abb. 7 eine Darstellung gegeben, die erkennen lässt, wie lange die verschiedenen Pflanzen die Wasserdecke vertragen haben, bevor ihr Ertrag im grossen ganzen verlorengegangen ist. In Anbetracht der verschiedenartigen Untersuchungsverhältnisse hat die Darstellung jedoch nur als richtunggebend zu gelten. Die Wiesenpflanzen scheinen im beginnenden Frühjahr, wenn der Boden gefroren ist, eine Wasserdecke bedeutend besser als im, Mittsommer vertragen zu haben. Die Kulturpflanzen zeigen sich am empfindlichsten gegenüber dem Hochwasser, das im Mittsommer, wenn der Wachstumsvorgang am lebhaftesten ist, auf die Kulturen steigt. In der Reifezeit können sie sogar eine verhältnissmässig lang andauernde Wasserdecke vertragen. Es ist beobachtet worden, dass sich die Abgangsgrenze undeutlich ausbildet, wenn das Hochwasser zeitig im Fruhjahr und gegen Ende der Vegetationszeit eintritt. Im ersteren Fall verursacht das Hochwasser hauptsächlich eine Lichtung des Bestandes, durch die die Undeutlichkeit der Abgangsgrenze bewirkt wird. Das in der Reifezeit eingetretene Hochwasser beeinflusst in erster Linie nur die Korngrösse, weswegen die Abgangsgrenze erst mittels Kornuntersuchungen festgelegt werden kann. 